\title{
Diversity and Organizational Development
}


This page intentionally left blank 


\title{
Diversity and Organizational Development: Impacts and Opportunities
}

\author{
AUTHORED BY \\ JENNIFER KUKLENSKI
}

Northland College, USA

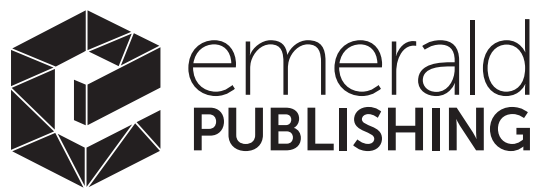


Emerald Publishing Limited

Howard House, Wagon Lane, Bingley BD16 1WA, UK

First edition 2021

Copyright (C) 2021 by Emerald Publishing Limited

All rights of reproduction in any form reserved

\section{Reprints and permissions service}

Contact: permissions@emeraldinsight.com

No part of this book may be reproduced, stored in a retrieval system, transmitted in any form or by any means electronic, mechanical, photocopying, recording or otherwise without either the prior written permission of the publisher or a licence permitting restricted copying issued in the UK by The Copyright Licensing Agency and in the USA by The Copyright Clearance Center. Any opinions expressed in the chapters are those of the authors. Whilst Emerald makes every effort to ensure the quality and accuracy of its content, Emerald makes no representation implied or otherwise, as to the chapters' suitability and application and disclaims any warranties, express or implied, to their use.

British Library Cataloguing in Publication Data

A catalogue record for this book is available from the British Library

ISBN: 978-1-83982-593-4 (Print)

ISBN: 978-1-83982-592-7 (Online)

ISBN: 978-1-83982-594-1 (Epub)

ISOQAR certified

Management System,

awarded to Emerald

for adherence to

Environmental

standard

ISOQAR

ISO 14001:2004. 
For Alex, Jenna, Paige, and Teigan 
This page intentionally left blank 


\section{Table of Contents}

List of Tables and Figures ix

List of Abbreviations $x i$

Acknowledgments xiii

Chapter 1 Introduction 1

Chapter 2 Diversity in Context 11

$\begin{array}{lll}\text { Chapter } 3 & \text { Defining Diversity } & 27\end{array}$

$\begin{array}{lll}\text { Chapter } 4 \text { Cultural Diversity } & 37\end{array}$

Chapter 5 Cognitive Diversity 51

Chapter 6 Social Exclusion 63

$\begin{array}{lll}\text { Chapter } 7 & \text { Embracing Diversity } & 77\end{array}$

$\begin{array}{lll}\text { Chapter } 8 & \text { Inclusive Organizational Development } & 87\end{array}$

Chapter 9 Inclusion and Organizational Culture 103

$\begin{array}{lll}\text { Chapter } 10 \text { Conclusion } & 113\end{array}$

$\begin{array}{ll}\text { References } & 123\end{array}$

$\begin{array}{ll}\text { Index } & 139\end{array}$ 
This page intentionally left blank 


\section{List of Tables and Figures}

Figure 2.1. Average Number of Labor Migrants Entering Select Countries, 2007-2017. 15

Figure 3.1. The Diversity Tree and Sample Attributes. 33

Figure 3.2. Single-Dimensional Versus Multi-Dimensional Diversity Frameworks.

Figure 4.1. Hofstede's Dimensions of National Culture and Sample Country Rankings. 39

Figure 4.2. Three of the Most Common Hand Gestures. 48

Figure 5.1. Flow of Time: Monochronic Versus Polychronic Time Orientation.

Figure 7.1. Pyramid of Corporate Social Responsibility (CSR).

Figure 8.1. Stages of Diversity and Inclusion Organizational Development (D\&IOD).

Figure 10.1. Equality versus Equity.

Table 2.1. Median Age in Select Countries 1950-2100 (Projected).

Table 2.2. Countries With Largest Percentage Change in Female Board Seats, 2010-2017.

Table 5.1. Summary of Relational Models Primary Characteristics. 
This page intentionally left blank 


\section{List of Abbreviations}

$\begin{array}{ll}\text { AA } & \text { Affirmative action } \\ \text { AR } & \text { Authority ranking } \\ \text { CS } & \text { Communal sharing } \\ \text { CSR } & \text { Corporate social responsibility } \\ \text { CVS } & \text { Chinese Value Survey } \\ \text { D\&I } & \text { Diversity and inclusion } \\ \text { D\&IOD } & \text { Diversity and inclusion organizational development } \\ \text { EAP } & \text { Employee assistance plan } \\ \text { EEOC } & \text { Equal Employment Opportunity Commission } \\ \text { EM } & \text { Equality matching } \\ \text { ESG } & \text { Environmental, social, and governance } \\ \text { EU } & \text { European Union } \\ \text { HR } & \text { Human Resources } \\ \text { IDV } & \text { Individualism } \\ \text { ILO } & \text { International Labour Organization } \\ \text { IRIC } & \text { Institute for Research on Intercultural Cooperation } \\ \text { IVR } & \text { Indulgence versus restraint } \\ \text { LTO } & \text { Long-term orientation } \\ \text { MAS } & \text { Masculinity } \\ \text { MCOD } & \text { Multicultural organizational development } \\ \text { MP } & \text { Market pricing } \\ \text { OD } & \text { Organizational development } \\ \text { OECD } & \text { Organization for Economic Cooperation and } \\ \text { PDI } & \text { Development } \\ \text { PRI } & \text { Power distance } \\ & \text { Protestant Relational Ideology } \\ \end{array}$


xii List of Abbreviations

SRI

STEM

UAI

UN

US

USSR

WHO

YEN
Socially responsible investment

Science, technology, engineering, and mathematics

Uncertainty avoidance

United Nations

United States

Union of Soviet Socialist Republics

World Health Organization

Young Employee Network 


\section{Acknowledgments}

The contents of this book span nearly 15 years of education, work, and research on diversity, inclusion, cross-cultural communication, and intercultural relationships in communities and organizations. Accordingly, my acknowledgments are directed toward those who helped me complete this book, as well as those who have informed my understanding of social justice issues, shaped my worldview, and inspired my practice.

I was first introduced to the concepts of cross-cultural understanding, tolerance, and inclusion by Dr Eddah Mutua. In her undergraduate communications course, I was put into uncomfortable but incredibly rewarding situations with people from all social backgrounds and identities. As someone raised in a small rural area with very little diversity, this experience was invaluable. Working under her leadership with Communicating Common Ground, I learned how to better communicate and empathize with people of diverse backgrounds and without such an experience, this book may never have come to fruition.

This work was completed with support from my colleagues at Northland College. Dr Kevin Schanning deserves special mention for sharing resources with me, encouraging me professionally, and informing me of the opportunity for course release that allowed me to dedicate more time to completing the book. To that end, I am also grateful to Dr Wendy Gorman for awarding me the course release that aided in my timely completion of the book. I would also like to extend gratitude to my Northland College students, especially those who have taken The Inclusive Workplace course. Their insights and careful consideration further sparked my own reflection on the challenging concepts covered in this book. I am particularly grateful for the detailed comments provided by Kelsie Shields and Bailey Wynn, who went above and beyond by reviewing a few draft chapters.

I would also like to acknowledge my Humanity in Action Diversity and Diplomacy Fellowship cohort for sharing their deeply personal stories and helping me confront my own privileges. These remarkable people helped me grow as an individual who will continue to work toward diversity, equity, and inclusion in all workplaces. I am also deeply grateful for the moral and intellectual support from Dr Tímea Varga, who has championed my research and inspired me to keep pushing forward even when giving up felt so much easier. Her willingness to always listen to me brainstorm ideas, as well as her design feedback, aided in the creative thinking necessary to make this book stand out among its peers.

Most importantly, I cannot thank my family and partner enough for their unwavering support of my many educational and professional pursuits. Frequent 
inquiries about the book and my progress from my father, brother, sister, and sister-in-law kept me motivated to finish so that I could finally share this book with them. Special recognition is deserved by my mother Mimi, who spent countless hours reading every chapter. She provided me with much needed critical and thorough feedback that helped propel the book toward its final version. Profound thanks is also extended to my partner, R.J., not only for his illustrative contribution in Chapter 3, but also for the many bouquets of flowers and bottles of champagne given to celebrate milestones in completing this work. 